\title{
Angles
}

New Perspectives on the Anglophone World

$11 \mid 2020$

Are You Game?

\section{Graphic Interlude}

Are you Game?

Winslow Homer, Ambrose Andrews, Briton Rivière, Sharon Lockhart, Anonymous, Marcus Gheeraerts I, Gawen Hamilton, Sir John Everett Millais, Thomas Rowlandson, Marion Post Wolcott, John Rogers, Mary Sargant Florence, Thomas Anshutz, Sir William Reynolds-Stephens and George Cruikshank

\section{(2) OpenEdition}

1 Journals

Electronic version

URL: https://journals.openedition.org/angles/3117

DOI: 10.4000 /angles.3117

ISSN: 2274-2042

Publisher

Société des Anglicistes de l'Enseignement Supérieur

\section{Electronic reference}

Winslow Homer, Ambrose Andrews, Briton Rivière, Sharon Lockhart, Anonymous, Marcus

Gheeraerts I, Gawen Hamilton, Sir John Everett Millais, Thomas Rowlandson, Marion Post Wolcott, John Rogers, Mary Sargant Florence, Thomas Anshutz, Sir William Reynolds-Stephens and George Cruikshank, "Graphic Interlude", Angles [Online], 11 | 2020, Online since 01 November 2020, connection on 08 June 2022. URL: http://journals.openedition.org/angles/3117 ; DOI: https://doi.org/10.4000/ angles. 3117

This text was automatically generated on 8 June 2022.

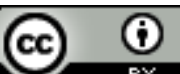

Angles est mise à disposition selon les termes de la Licence Creative Commons Attribution 4.0 International. 


\section{Graphic Interlude}

Are you Game?

Winslow Homer, Ambrose Andrews, Briton Rivière, Sharon Lockhart, Anonymous, Marcus Gheeraerts I, Gawen Hamilton, Sir John Everett Millais, Thomas Rowlandson, Marion Post Wolcott, John Rogers, Mary Sargant Florence, Thomas Anshutz, Sir William Reynolds-Stephens and George Cruikshank

Game as Amusement, Fun, Pleasure 
Winslow Homer (1836-1910), Snap the Whip (1872) - Oil on canvas (30.5x 50.8cm)

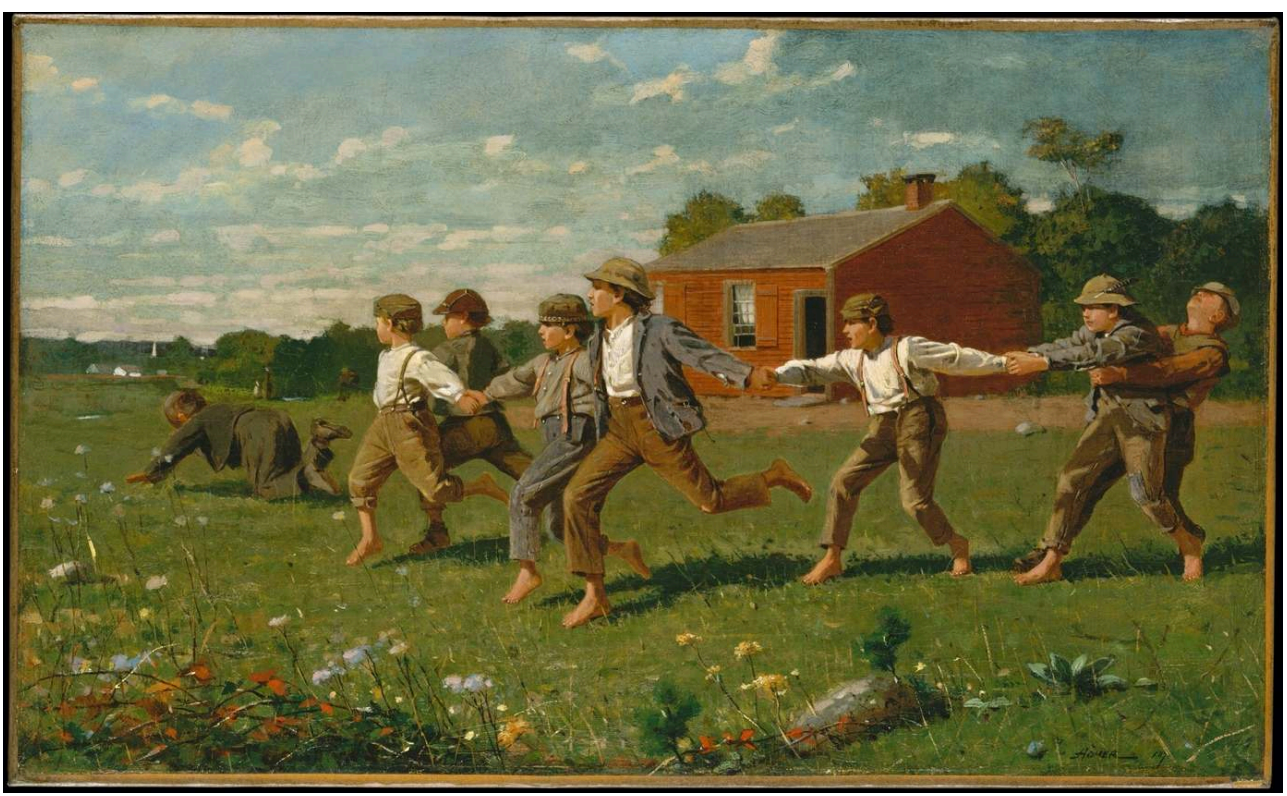

This outdoor scene is one of many painted by Winslow Homer, one of the most famous American artists of the nineteenth century. Children at play was a popular subject at the time. Here, probably after attending a lesson in the red schoolhouse in the background, the bare-footed boys are playing the game of snap the whip, where one child (the head) runs in all directions with the others holding the previous player by the hand. As an exercise in coordination and physical strength, it is easy to understand the metaphorical meaning Homer puts into his picture made after the Civil War. Even in this seemingly anecdotal genre painting, gaming takes on a more serious meaning.

Source: New York, Metropolitan Museum of Art. https://www.metmuseum.org/art/collection/search/ 11140 
Ambrose Andrews (1801-1877), The Children of Nathan Starr (1835) -Oil on canvas (72.1 x $92.7 \mathrm{~cm})$

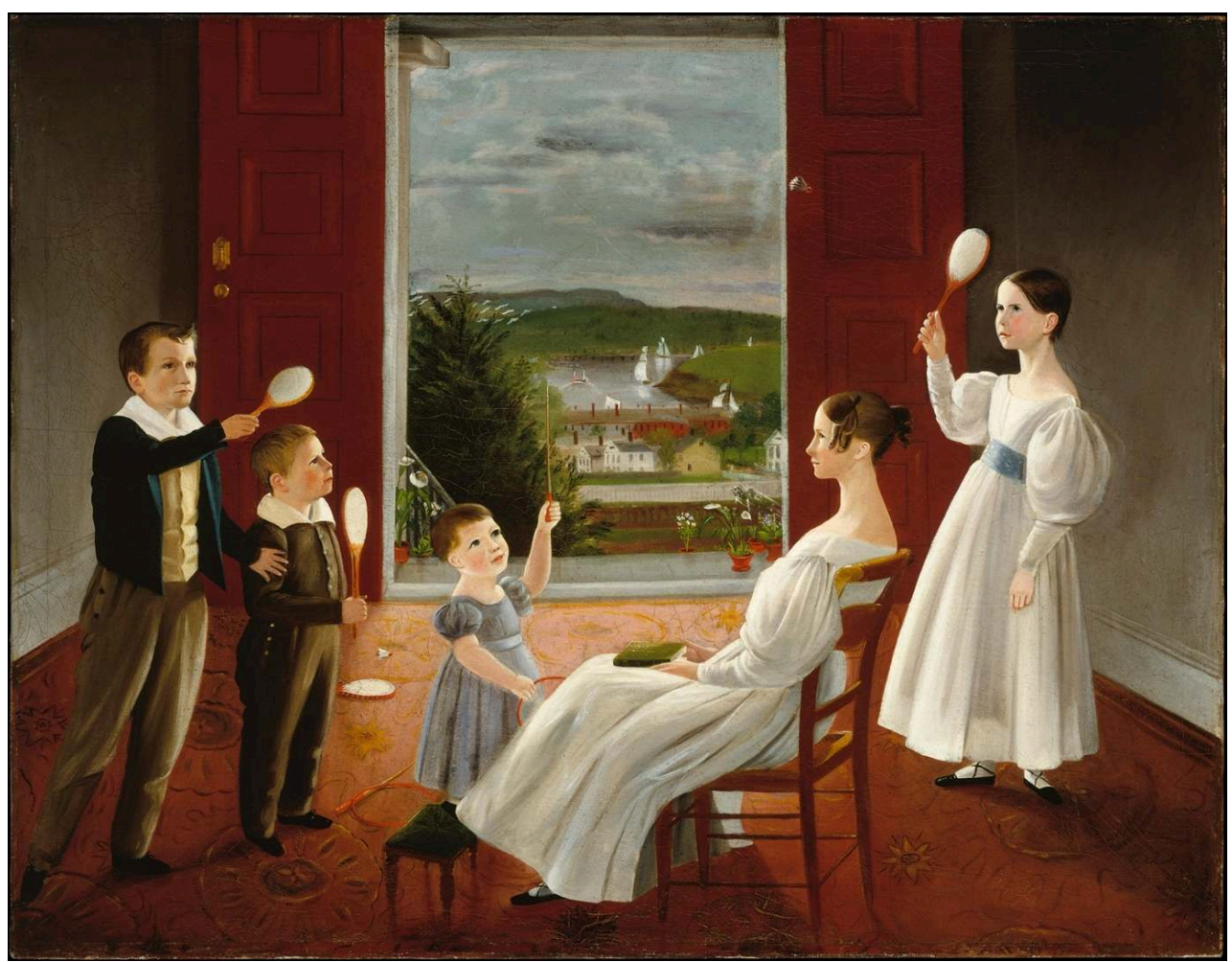

Here again children are at the centre of focus in this rather eerie indoor scene presenting a mother with her children playing "battledore and shuttlecock". What seems to be a peaceful and quiet scene of domestic happiness actually begs for explanation. The children look very grave and while the oldest play the same game, the youngest one, Edward, with a hoop in his right hand, points his gaming stick heavenward. As he died in 1835, the painting may be a memorial piece.

Source: New York, Metropolitan Museum of Art. https://www.metmuseum.org/art/collection/search/ 10077 
Briton Rivière (1840-1920), Giants at Play (1882) - Oil on canvas $(83.8$ x $135.3 \mathrm{~cm})$

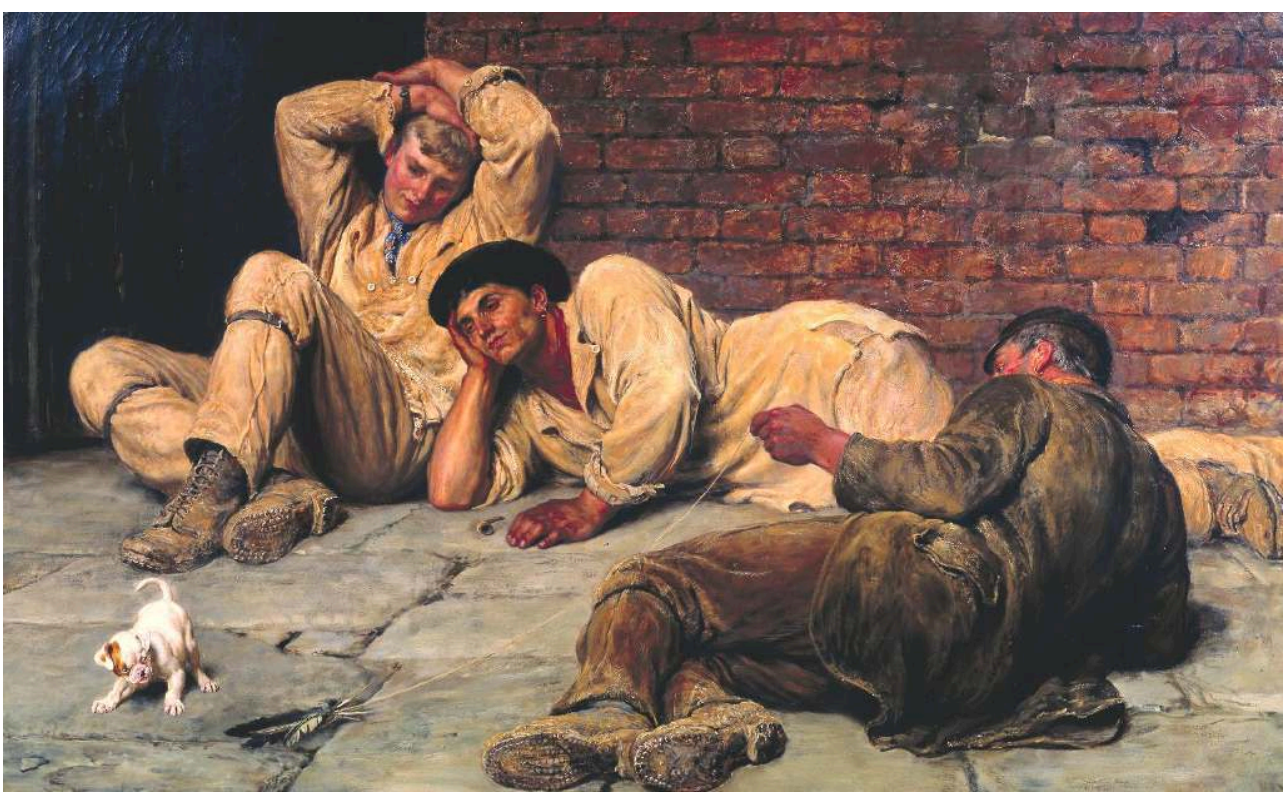

In the Victorian period, Briton Rivière specialised in scenes with animals - this is one instance of them. The three labourers at rest are playing with a tiny dog with string and feather. The dog being a bull-pup, one might imagine that this apparently innocent game is a way of training the animal for fighting.

Source: London, Tate Modern Gallery. https://www.tate.org.uk/art/artworks/riviere-giants-at-playn01516 

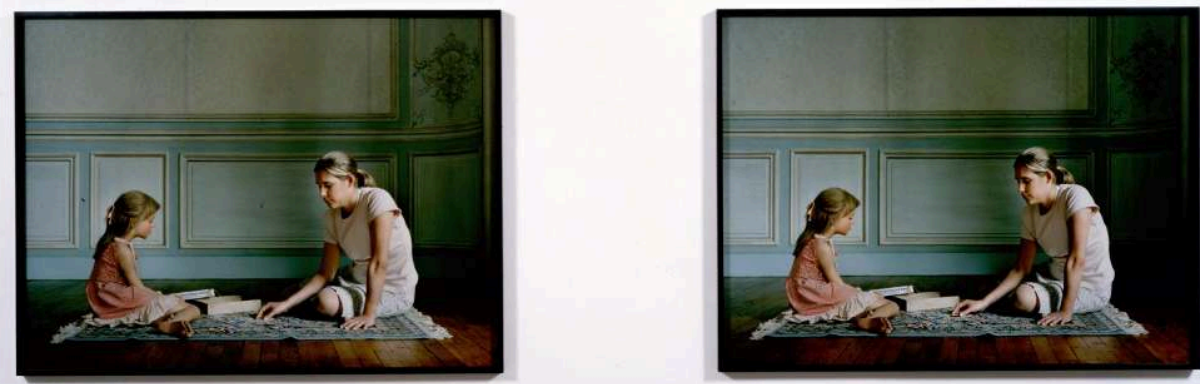

Have you had a good look at it? What do you see? "Two identical photographs of a mother playing with her daughter Maja," you say. Are you absolutely sure? Actually, in the second snapshot, the woman has slightly lifted her hand to place a piece of the puzzle. Yes, it is almost imperceptible. But it is not the only deceiving element in this work of art: the mother is in fact Duane Hanson (1925-1996), the famous American hyper-realist sculptor and what we all take to be her daughter is nothing but a life-size sculpture of Maja, from the work entitled Child with Puzzle (1978), including the rug and the jigsaw puzzle. Photography or the power of illusion (from the Latin illudere) - or when the artist plays games with the viewers.

(c) Sharon Lockhart. Source: London, Tate Modern Gallery. https://www.tate.org.uk/art/artworks/ lockhart-maja-and-elodie-p13234

\section{The Game and Its Rules}


Die, Roman period (30 B.C.-330 A.D.) - Ivory (1 cm square)

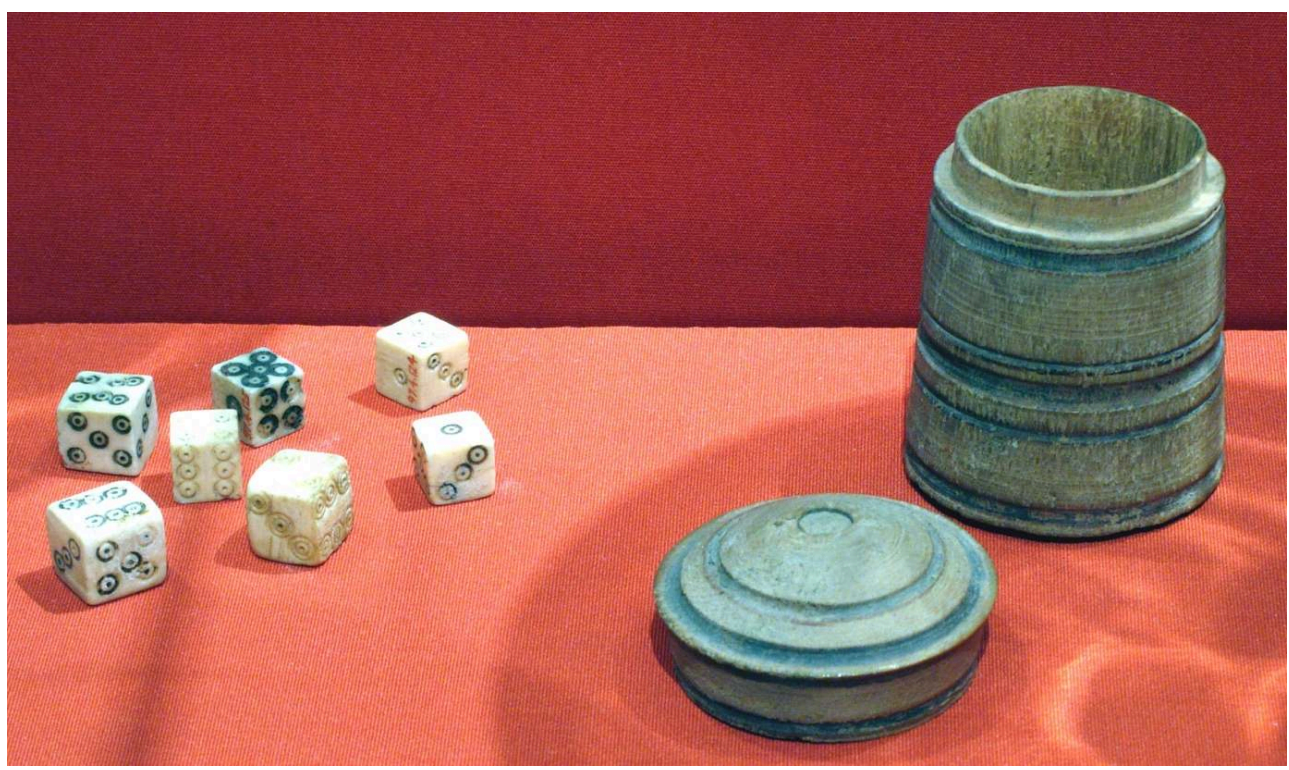

The dice with which the Roman soldiers gambled Christ's tunic (see below) might have looked like the ones shown here.

Source: New York, Metropolitan Museum of Art. https://www.metmuseum.org/art/collection/search/ 547960 
Marcus Gheeraerts I (1561/62-1635-36), from the series Passio Verbigenae Quæ Nostra Redemptio Christi (1575-1600) - Engraving (16 x $11.23 \mathrm{~cm}$

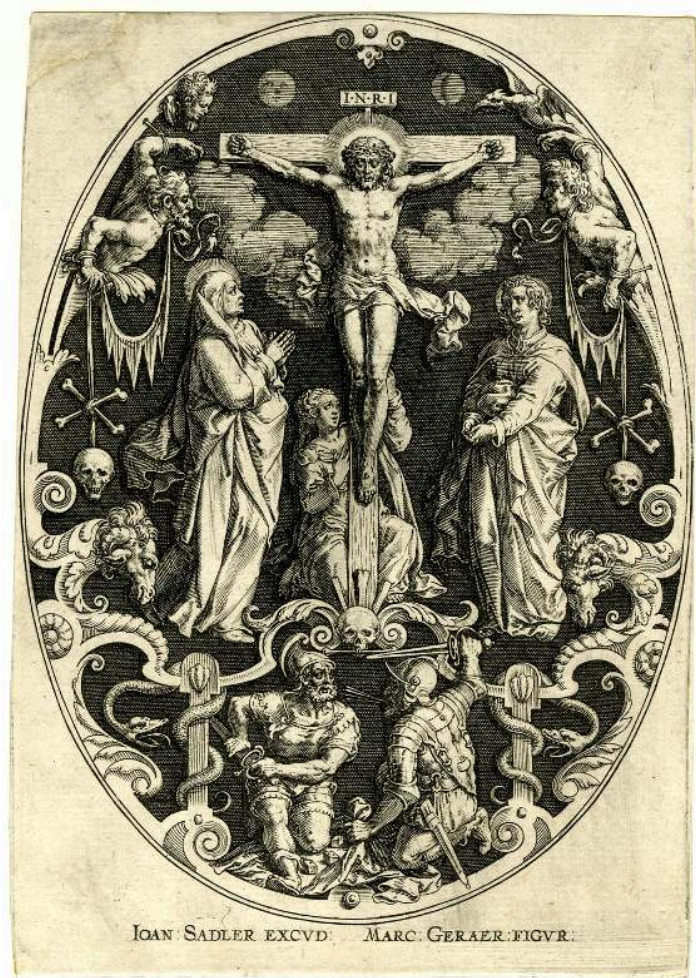

As a Calvinist, Marcus Gheeraerts I, born in Bruges, fled the Spanish Low Countries around 1567 with his son Marcus Gheeraerts the Younger (also a painter), before returning to the Netherlands around 1576 and to London again in 1586. In this engraving, the two Roman soldiers at the bottom are seen engaged in a raw that is about to turn to a fight. The stake of the game of dice is Christ's tunic, which the soldier on the right has already grabbed with his left hand while brandishing his sword with his right hand. This representation of gambling is very much in keeping with the moral treatises flourishing in early modern England: their authors usually warned their readers about the dangers of such games of chance, leading to cheating and therefore to quarrelling.

(C) The Trustees of the British Museum. https://www.britishmuseum.org/collection/object/ P_1861-0608-12 
Attr. to Gawen Hamilton (c. 1698-1737), An Elegant Company Playing at Cards (c. 1725) - Oil on canvas $(69.2 \times 57.7 \mathrm{~cm})$

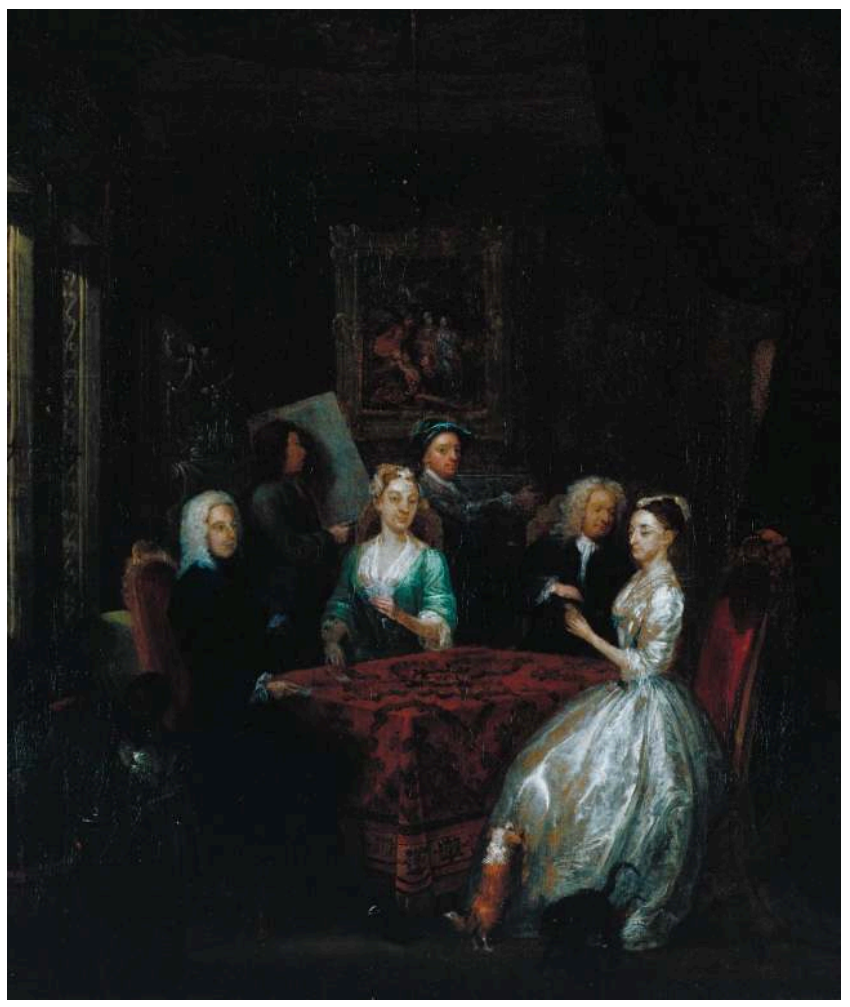

No such thing happens in this eighteenth-century conversation piece attributed to Gawen Hamilton (previously thought to be by Hogarth). The game of cards is presented here as one of the refinements of elegant society, the members of which (probably the Thornhill family) seem to be patrons of the art, to judge by the presence of a painter in the background.

Source: London, Tate Modern Gallery. https://www.tate.org.uk/art/artworks/hamilton-an-elegantcompany-playing-cards-t00943 
Sir John Everett Millais (1829-1896), Hearts are Trumps (1872) - Oil on canvas (165.7 x $219.7 \mathrm{~cm})$

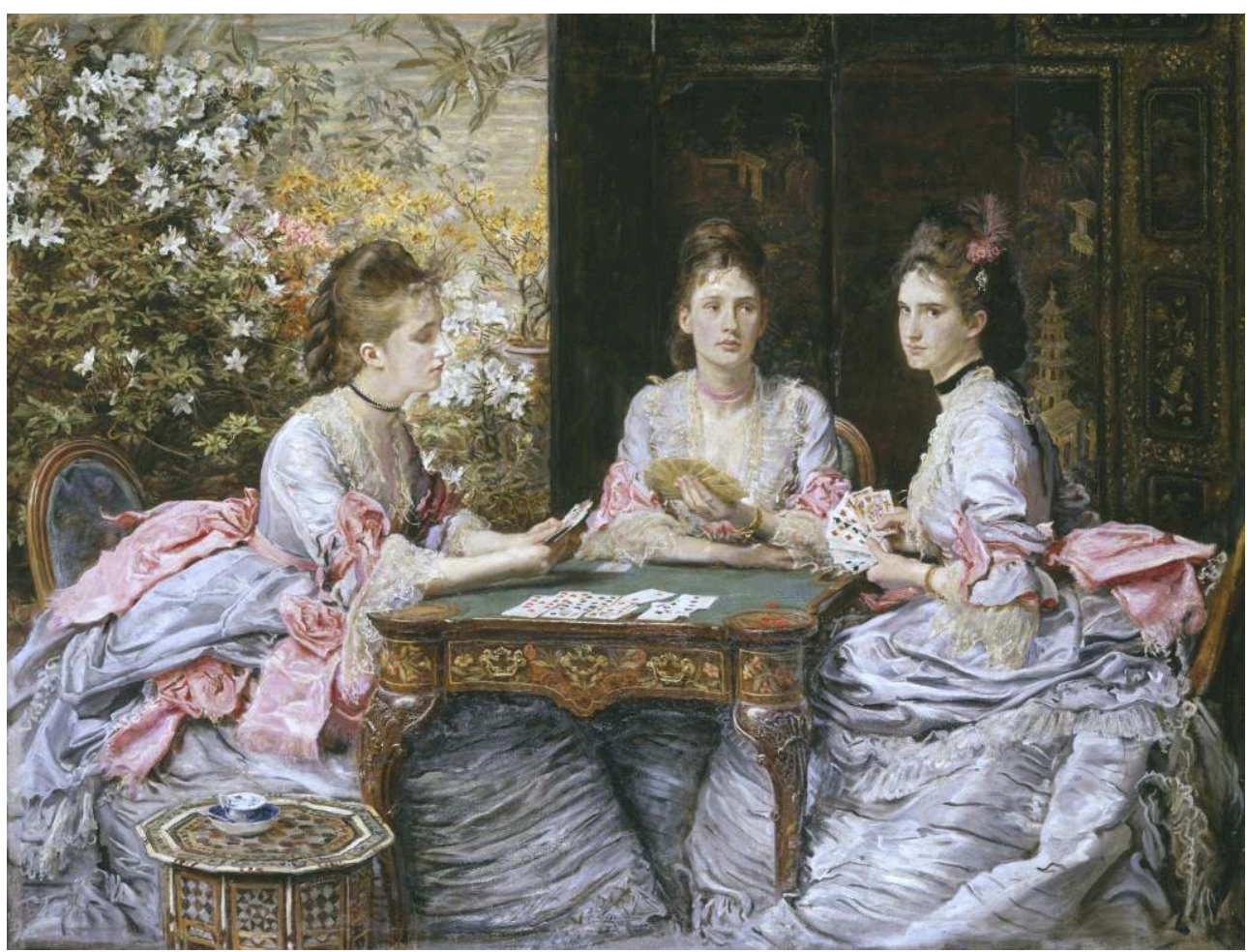

The title of this large piece - a commission from Walter Armstrong - works as double entendre. While it refers to the suit of cards (Hearts) chosen as trumps in a game of what could be bridge or whist, the presence of three young women at the table suggests there is more to it. They do not seem particularly interested in the game. Art history tells us that they are Armstrong's daughters: Elizabeth, Diana and Mary on the right. The latter, looking straight at the viewer, is holding most of the trump cards, which makes the picture a possible allusion to the competition the sisters are engaged in to find a husband. The literary quality of the painting cannot but remind the viewers of Jane Austen's novels (see Jean-Jacques Lecercle's article).

Source: London, Tate Modern Gallery. https://www.tate.org.uk/art/artworks/millais-hearts-are-trumpsn05770 
Thomas Rowlandson (1757-1827), Kick Up at a Hazard Table (1787) -Hand-coloured etching and aquatint $(40.9 \times 54.4 \mathrm{~cm})$

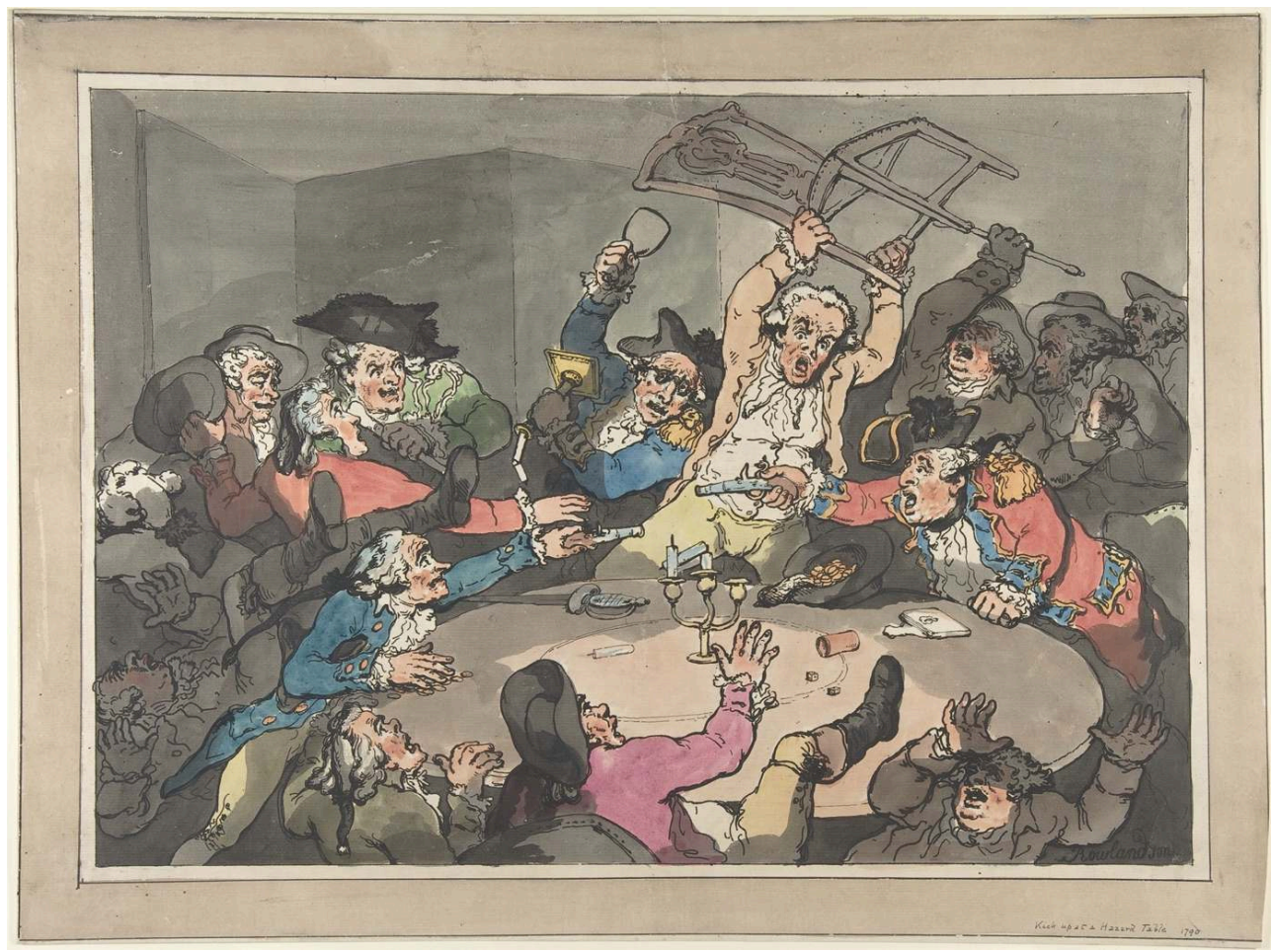

On the satirical side, this English cartoon is a vivid and humorous depiction of the untoward consequences of gambling in a masculine environment. No doubt cheating has been the rule and the stakes have raised high (see the hat filled with gold coins). All sorts of objects are wielded around: pistols, a candlestick, a chair, a glass, not to mention the sword on the table. Anything goes to attack one's adversary. What a shamble! The use of lights and shades is particularly dramatic and efficient in conveying a sense of utter chaos among the participants, coming from different ranks of society. The English officer on the right aims his pistol at an elderly man with a pigtail (a Frenchman), trying to protect his winnings. It is rather ironic that the author of this moralizing picture denouncing the hazards of gambling should have dilapidated his fortune by $1793 . .$.

Source: New York, Metropolitan Museum of Art. https://www.metmuseum.org/art/collection/search/ 392858 
Marion Post Wolcott (1910-1990), Gambling (skin game) in juke joint on Saturday night, near Moore Haven, Florida (1941) - Gelatin silver print $(27.9 \times 35.6 \mathrm{~cm})$

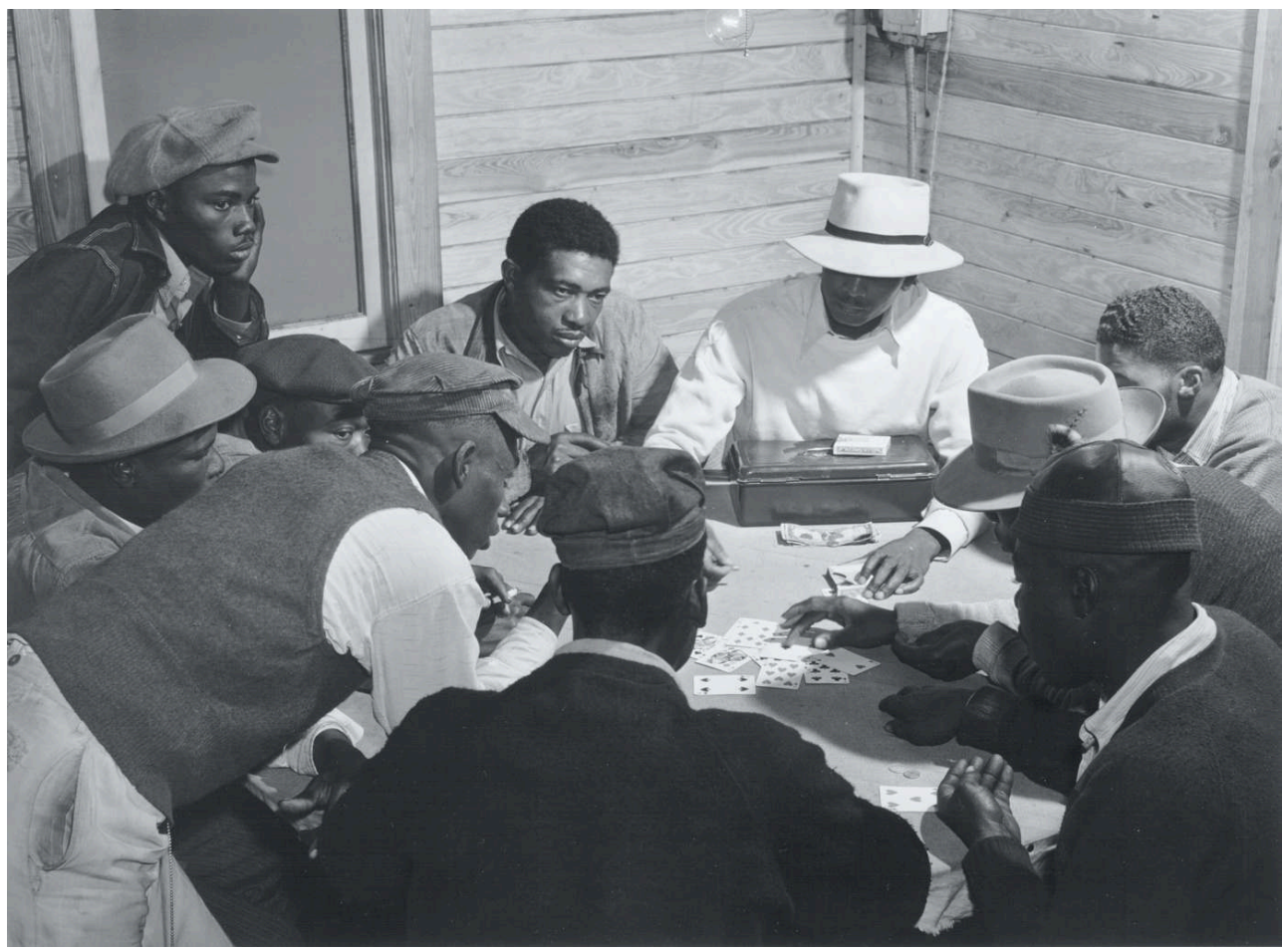

During the Great Depression, Marion Post Wolcott worked as a documentary photographer for the US Farm Security Administration. Her photographs (and those of others, like Dorothea Lange and Walker Evans) constitute a unique testimony on the state of American society at a time of great economic and racial inequalities. "As an FSA documentary photographer, I was committed to changing the attitudes of people by familiarizing America with the plight of the underprivileged, especially in rural America," she once said. The photo kept in the Smithsonian collection shows African Americans playing "skin game" - also simply designated as "skin" - defined by the OED as "U.S. (chiefly in African-American usage). A card game in which players are each dealt a single card and then bet on that card not being the first to be matched in value by another dealt from the pack".

(c) Washington (D.C.), Smithsonian American Art Museum. https://americanart.si.edu/artwork/ gambling-skin-game-juke-joint-saturday-night-near-moore-haven-florida-36665

\section{Chess}


Knight Chess Piece (c. 1250) - Walrus ivory $(7.8 \times 6.5$ × $3.5 \mathrm{~cm})$

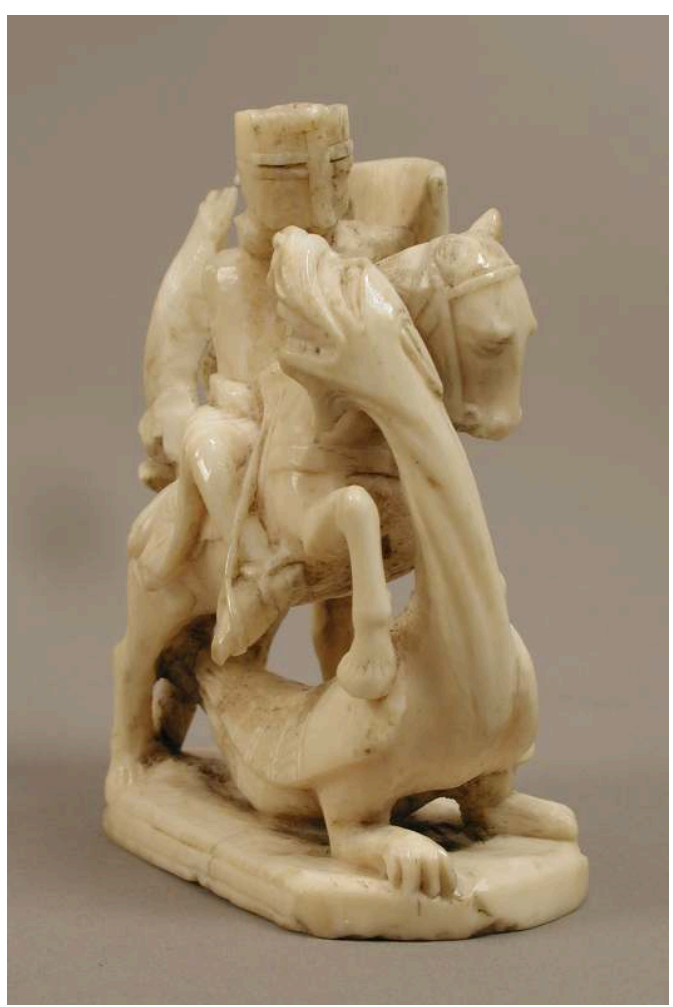

This fine piece of medieval craftsmanship reminds us that chess is one of the oldest games invented by Man, perhaps in India around the sixth century A.D. It has become very popular throughout the world, even among children, as the pictures below illustrate.

(C) The Trustees of the British Museum. https://www.metmuseum.org/art/collection/search/464233 
John Rogers (1829-1904), Checkers up at the Farm (1875) - Painted plaster (51.9 x 44.6 x $32.2 \mathrm{~cm}$ )

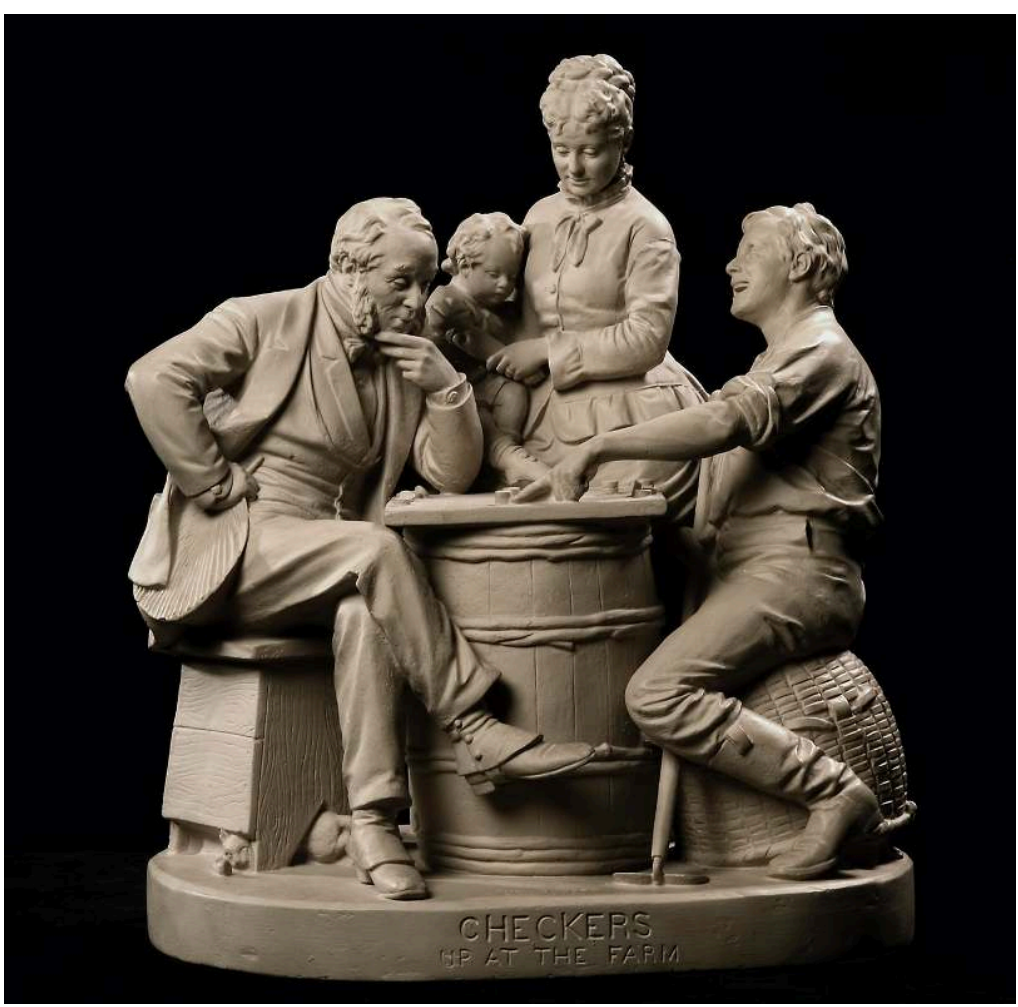

In this (rather wealthy) farmer's family, chess is part of everyday life, perhaps because, as a game absolutely excluding the notion of chance (with no hidden information), it escaped the moral strictures attached to other games involving it (like dice and cards). In any case, this family scene was so popular with the public that the sculptor sold 5,000 copies of it.

Source: Washington, D.C. Smithsonian American Art Museum. https://americanart.si.edu/artwork/ checkers-farm-21138 
Mary Sargant Florence (1857-1954), Children at Chess (c. 1903) - Tempera on wood (90 x $40 \mathrm{~cm})$

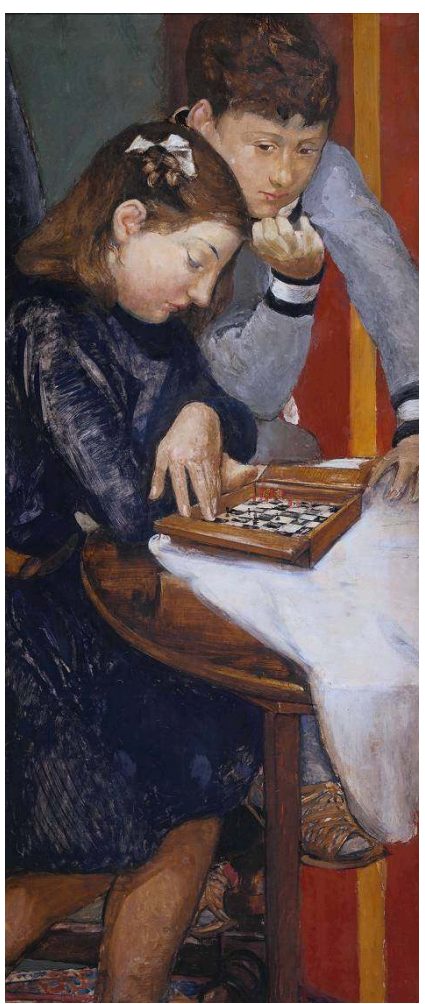

Now in this painting no adult is there to play or see the game: the painter's children are absorbed in thought, the brother wondering what her sister's next move will be. There is no doubt that the game is part of Sargant Florence's modern educational views. As a committed feminist (she was a

suffragette), she wanted her children to equally develop all their abilities: her daughter Alix became a psychoanalyst and her son Philip an economist.

(c) Reserved. Source: London, Tate Modern Gallery. https://www.tate.org.uk/art/artworks/florencechildren-at-chess-n05960 
Thomas Anshutz (1851-1912), Checker Players (c. 1895) - Oil on canvas (40.8 x $51 \mathrm{~cm})$

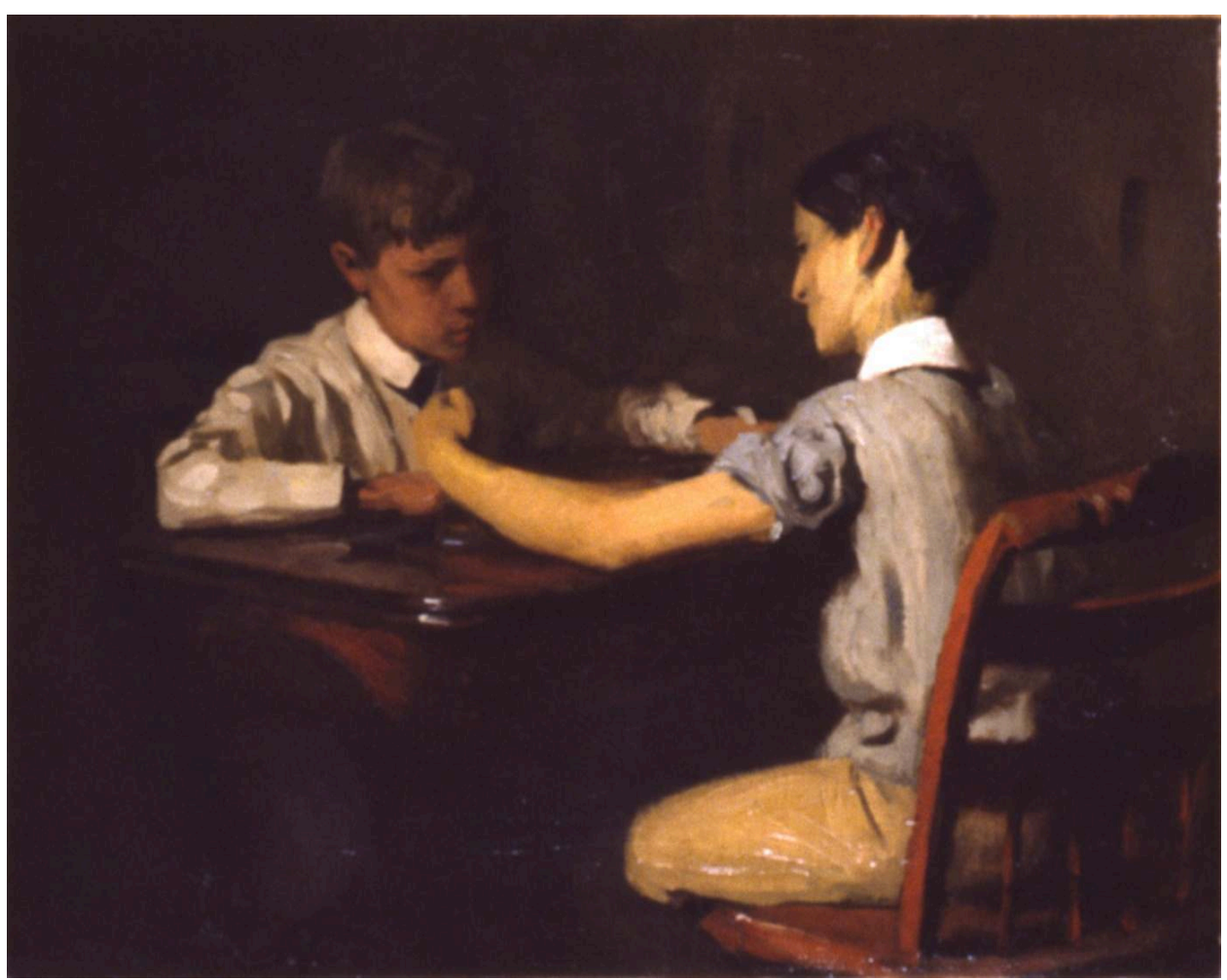

Even though the game is not exactly chess, but checkers, children are shown to be as engrossed in it as the previous ones. A student of Thomas Eakins, Anschutz was also an arts teacher and founded the Darby School (1898), promoting plein air painting.

Source: Washington (D.C.), Smithsonian American Art Museum, Gift of Orrin Wickersham June. https://americanart.si.edu/artwork/checker-players-440

\section{Game \& Education}

It is now clear that playing games can serve educational purposes, as the following items will show. In 1677 was published a small book entitled Grammatical Cards, containing four suits of cards: Orthographia, Prosodia, Etymologia and Syntaxis intended to teach the rules of grammar (in Latin). 
Grammatical Cards (published in London by S. Mearn and A. Clark, 1677. Imprimatur of J. Jane June $\left.1^{\text {st }} 1676\right)$, Titlepage

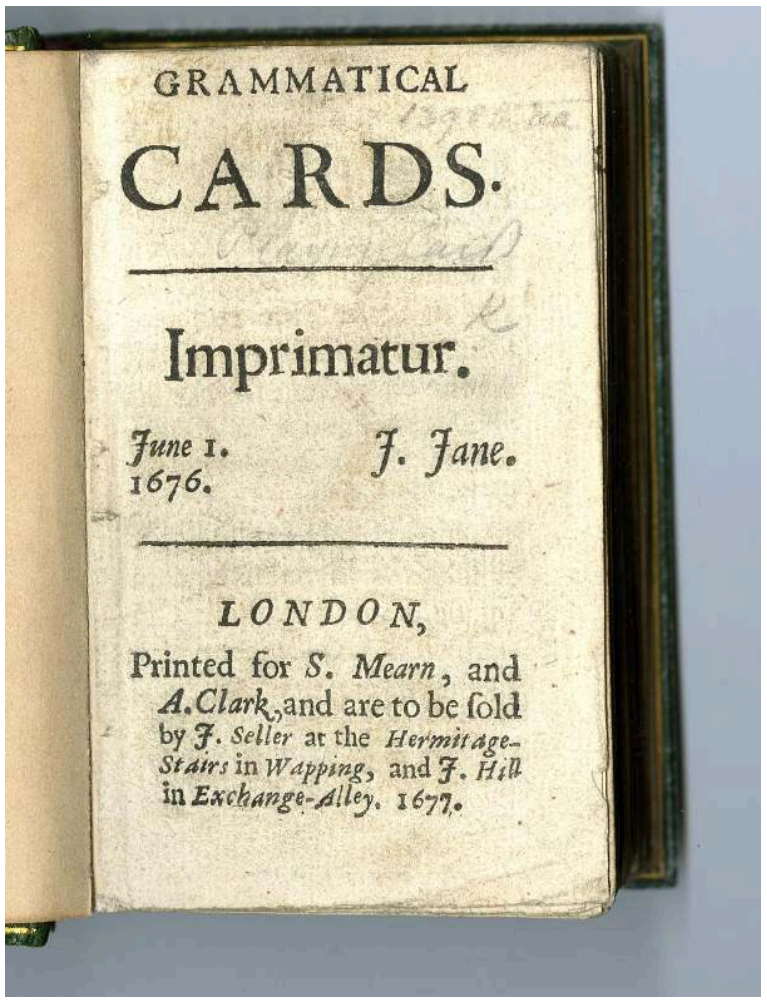

(c) The Trustees of the British Museum. https://www.britishmuseum.org/collection/object/P_1982U-4625-7-52 
Grammatical Cards (published in London by S. Mearn and A. Clark, 1677. Imprimatur of J. Jane June $\left.1^{\text {st }} 1676\right)$, "Orthographia"

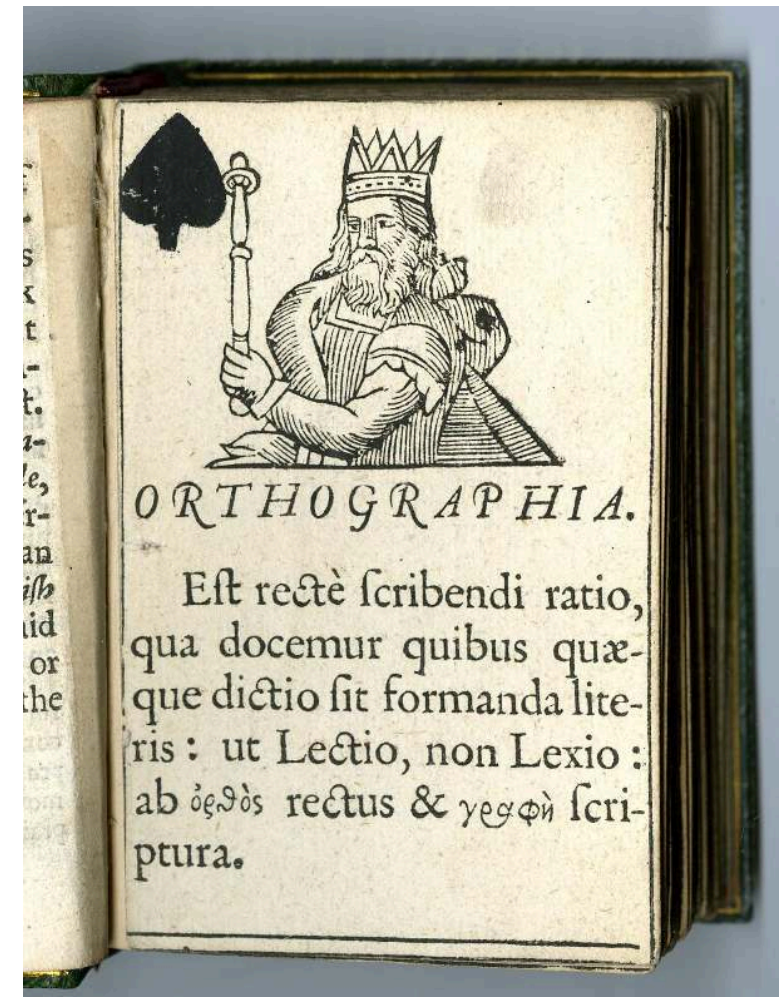

"Orthography: It is the method of writing correctly by which we learn how to spell each pronunciation Thus Lectio and not Lexio. The word comes from orthos, meaning right, and graphè, meaning writing." (c) The Trustees of the British Museum. https://www.britishmuseum.org/collection/object/P_1982U-4625-7-52 
Grammatical Cards (published in London by S. Mearn and A. Clark, 1677. Imprimatur of J. Jane June $\left.1^{\text {st }} 1676\right)$, "Orthographia"

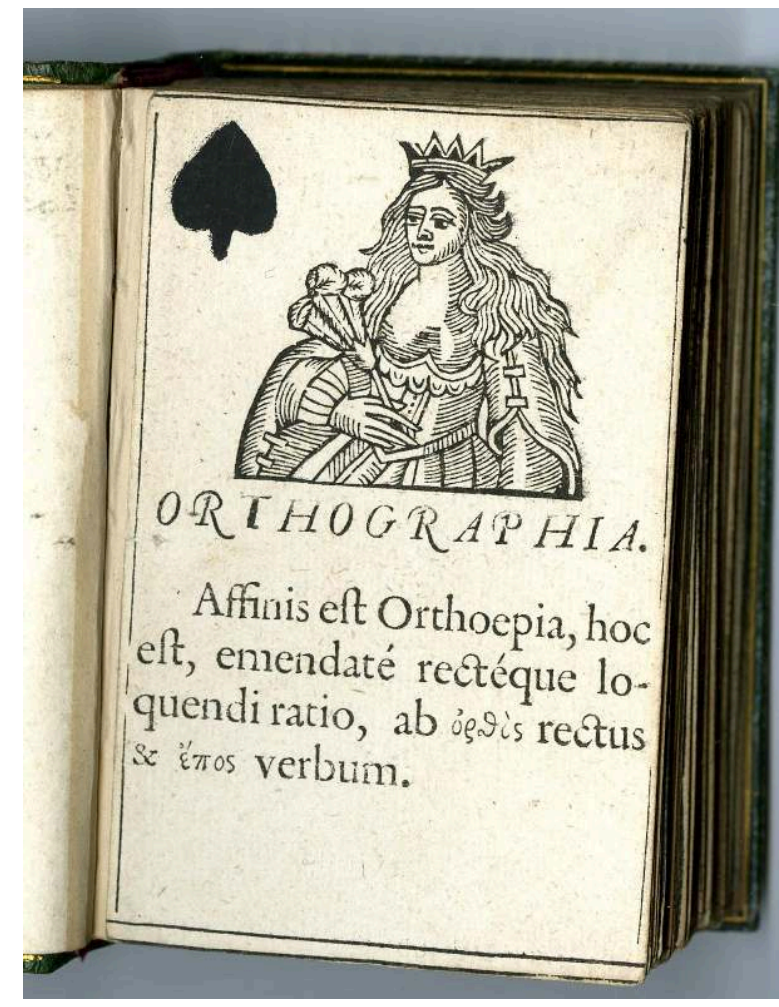

"Close to orthography is orthopeia (the method of speaking correctly), that is to say speaking correctly and accurately." (Translation into English from a French translation made by Christian Leroy)

(c) The Trustees of the British Museum. https://www.britishmuseum.org/collection/object/P_1982-

U-4625-7-52

\section{Game as Metaphor}

2 Some of the previous images were proof that gaming was often used both literally and metaphorically in the arts. Here, I would like to pause on a few illustrations of games as political metaphors. 
Sir William Reynolds-Stephens (1862-1943), A Royal Game (1906-1911) - Bronze, wood and stone $(240.7 \times 233 \times 97.8 \mathrm{~cm})$

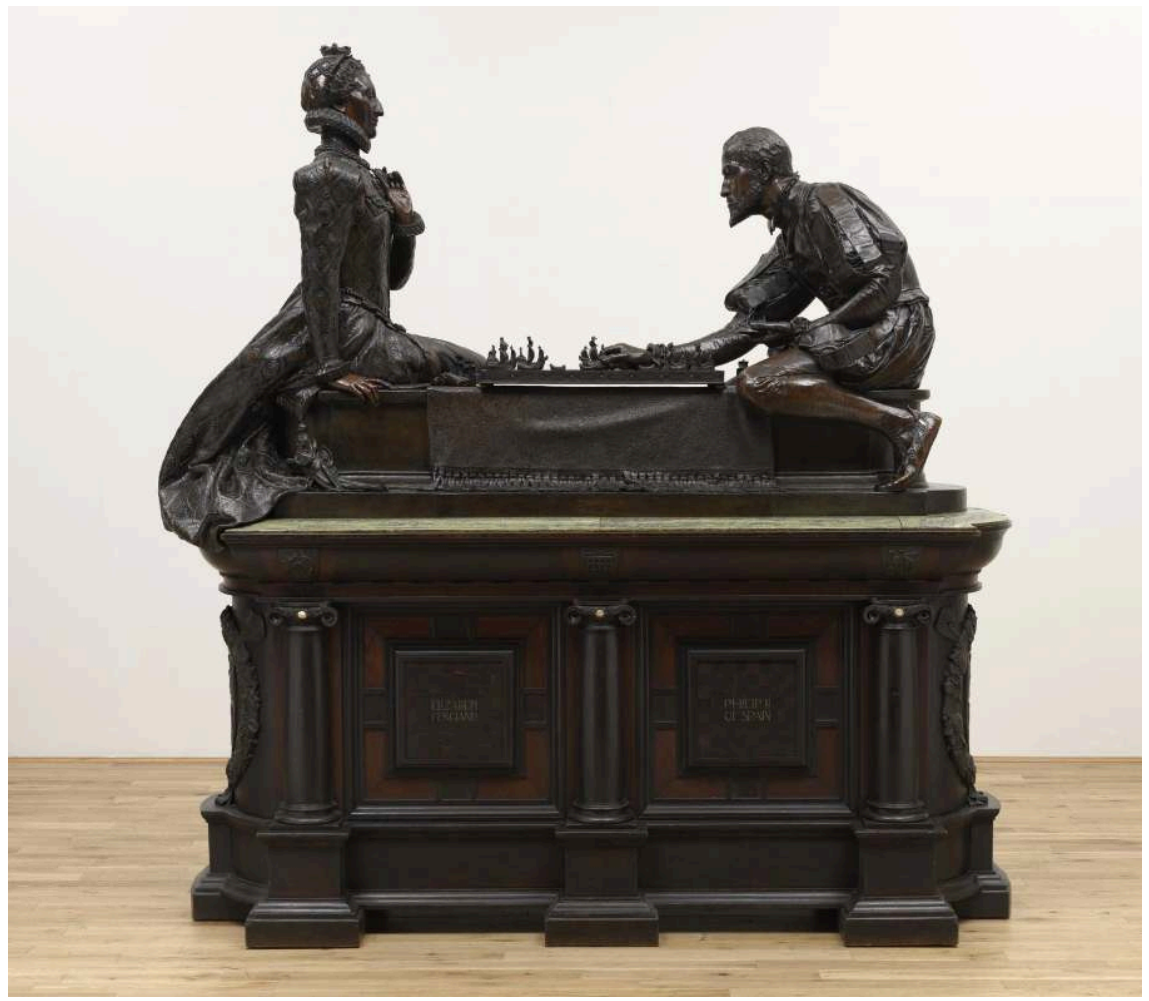

This spectacular sculpture evokes the famous episode of the defeat of the Spanish Armada in 1588. The chess pieces are replaced by ships representing the English and Spanish fleets. A regal Elizabeth I is opposed to Spanish King Philip II in a game he is about to lose. This is reminiscent of the use Thomas Middleton made of the game in his Game at Chess (1624), the title page of which figures a game of chess played between the "Black House" and the "White House".

Source: London, Tate Modern Gallery. Photo ( Tate. https://www.tate.org.uk/art/artworks/reynoldsstephens-a-royal-game-n02788 
Anonymous, The Gamblers (1785) - Hand-coloured etching $(24.9 \times 34.1 \mathrm{~cm})$

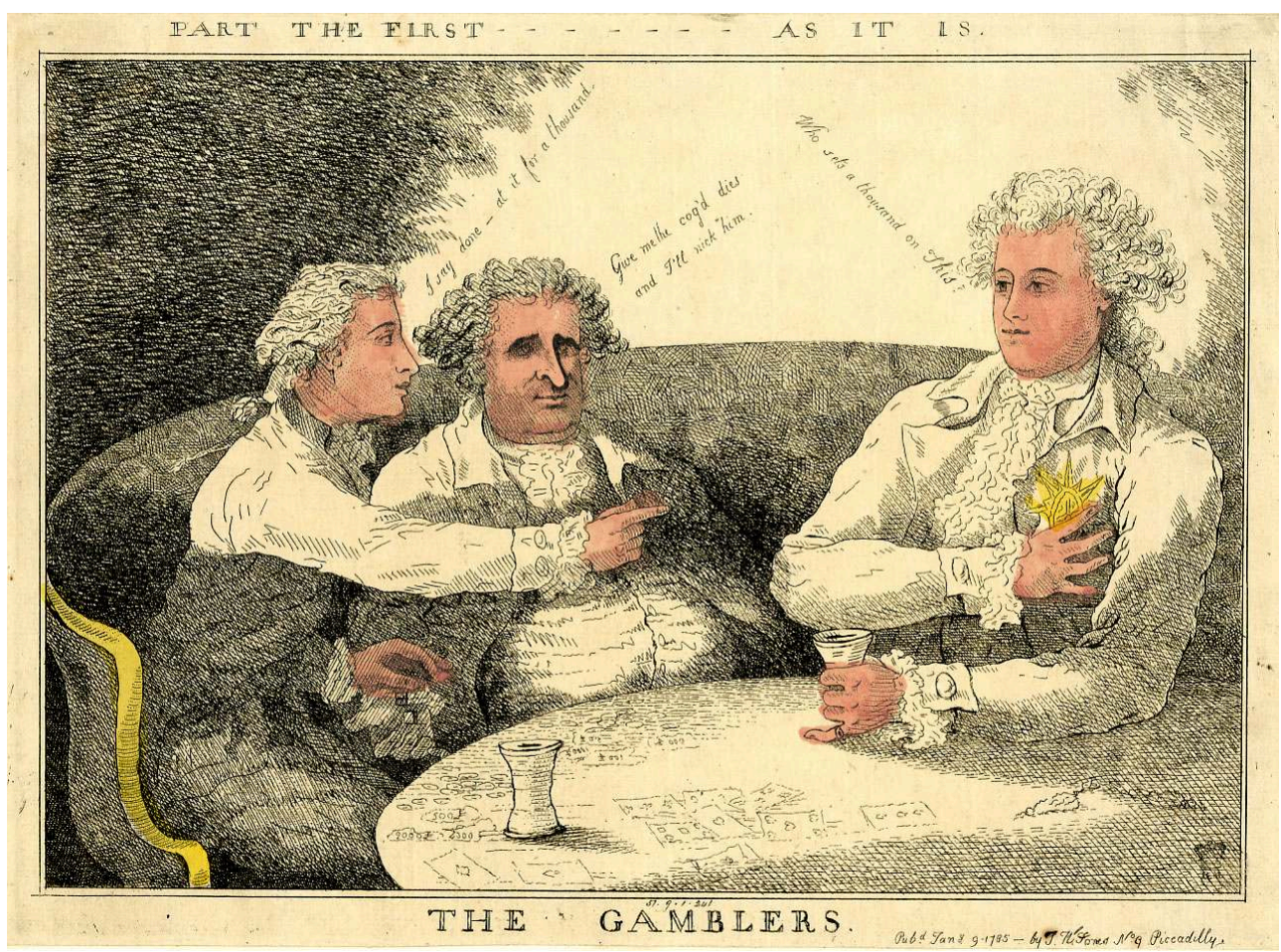

The gamblers sitting around the table are the Prince of Wales (on the right, saying: "Who sets a thousand on this?"), Fox, the Whig statesman leading His Majesty's Opposition (in the middle, saying: "Give me the cog'd dies and I'll nick him") and, perhaps, Sheridan, a friend and supporter of Fox's (on the left, answering: "I say done - at it for a thousand"). This satire on the bad influence of Fox (trying to cheat) on the Prince of Wales is one of the many circulating at the time.

(C) The Trustees of the British Museum. https://www.britishmuseum.org/collection/object/

P_1851-0901-241 
George Cruikshank (after George Humphrey), A Game at Cribbage or Boney's Last Shuffle (1814) Hand-coloured etching $(21.2 \times 27.5 \mathrm{~cm})$

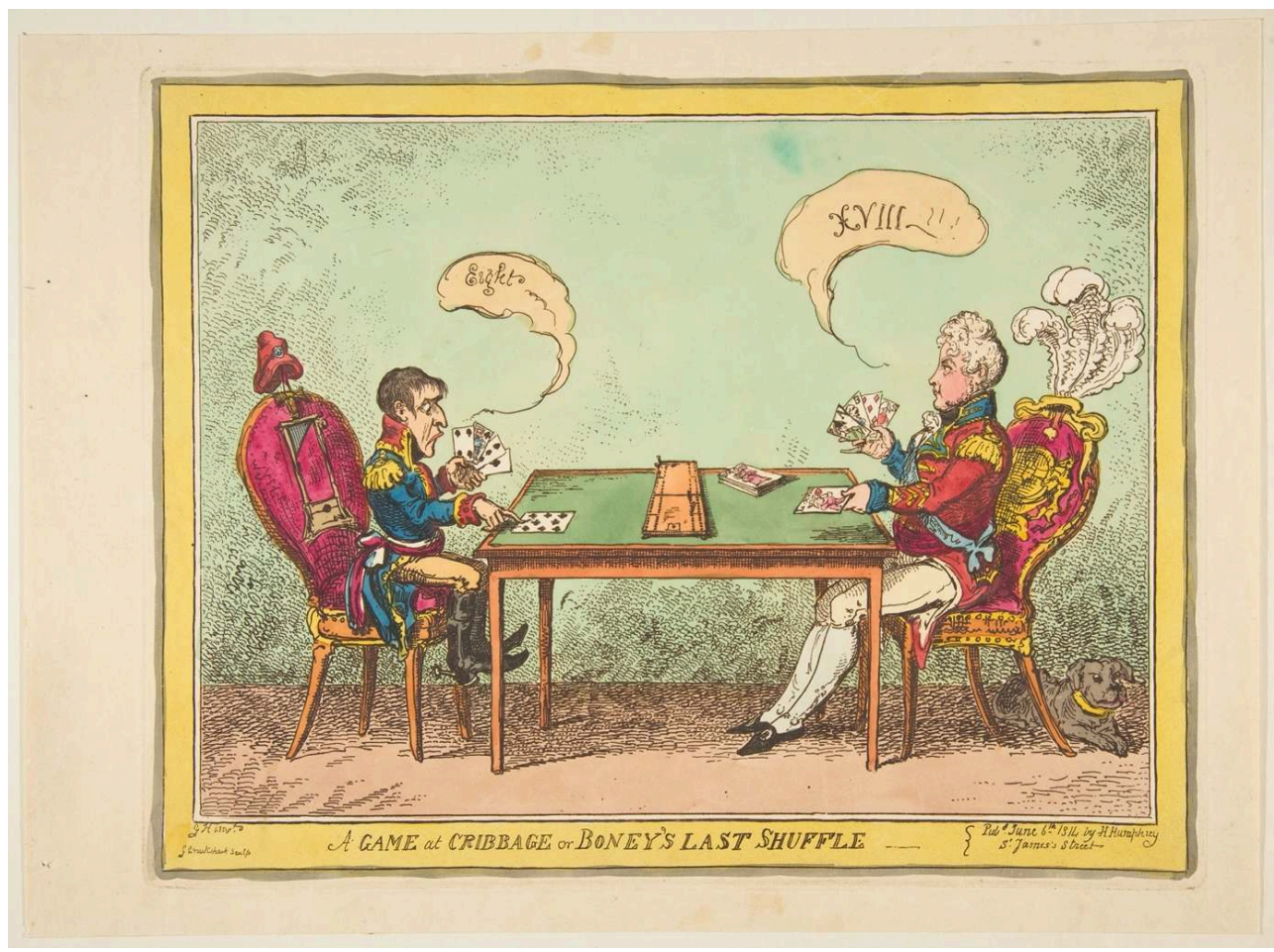

In this cartoon, the anonymous English artist pokes fun at Napoleon after his abdication on 6 April 1814. In this game of cribbage, he is opposed to the Regent (the Prince of Wales in the previous cartoon) who, comfortably sitting in a chair adorned with the Royal Arms, triumphantly holds a winning card (a king of hearts) and exclaims "XVIII!!!" in reference to the Restoration of the Bourbons, while the defeated emperor, looking dismayed, puts an eight of clubs on the table. The date of publication of the etching corresponds to the day of the arrival of the Allied sovereigns in England and the author gives credit to the Regent for the restoration of Louis XVIII.

Source: New York, Metropolitan Museum of Art. https://www.metmuseum.org/art/collection/search/ 389106

\section{Post-scriptum: Game or Game?}


Thomas Rowlandson (1757-1827), The Huntsman Rising; The Gamester Going to Bed ([July 31, 1809], reissued 1811) - Hand-coloured etching $(34 \times 23.1 \mathrm{~cm})$

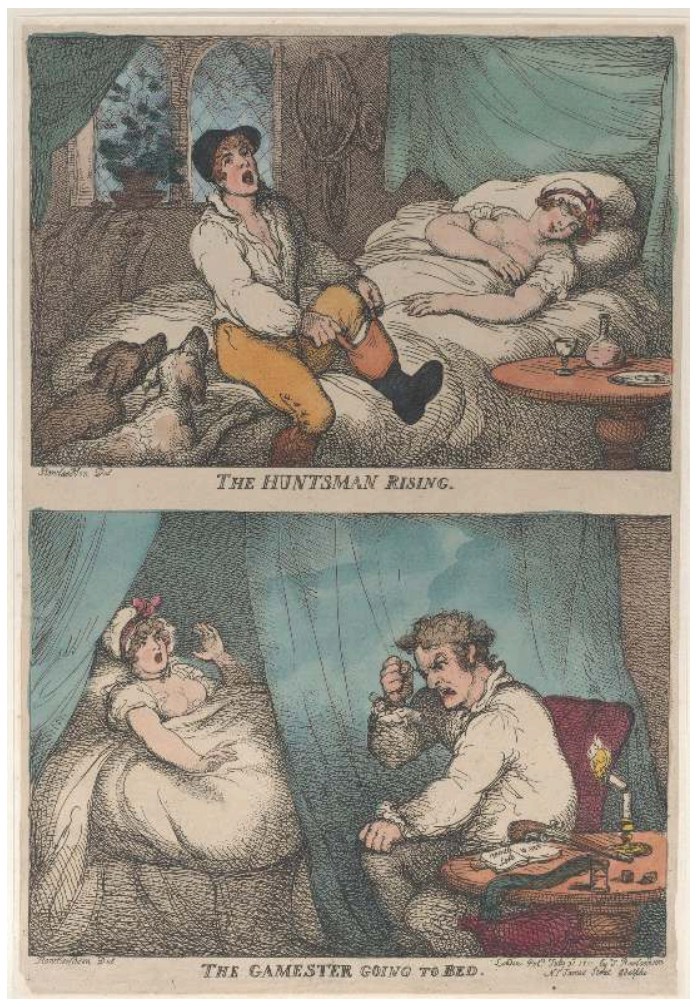

In an interesting juxtaposition, this etching by Rowlandson (see above one of his other engravings) enables us to slip from meaning II ("An activity played for entertainment, according to rules, and related uses") of the word "game" in English (OED) to meaning III: "Senses relating to hunting and the chase" $(O E D)$. The moralistic tone of the image is unmistakable: while the early-rising hunter contributes to the happiness of his wife and home, the gamester, coming back late from an unsuccessful game of dice, brings enormous debts $(£ 10,000)$ as well as disarray at home, to the great indignation of his wife.

Source: New York, Metropolitan Museum of Art. https://www.metmuseum.org/art/collection/search/ 786255

\section{ABSTRACTS}

This graphic interlude features a selection of pictures which can illustrate the topic of this issue: "Are you Game?".

Cet interlude iconographique comporte une sélection d'images illustrant à leur manière le thème de ce numéro: « Êtes-vous prêt(e) à jouer?».

\section{INDEX}

Keywords: games, chess, cards, painting, caricature, satire

Mots-clés: jeux, échecs, cartes, peinture, caricature, satire 